\title{
ACER2 Gene
}

National Cancer Institute

\section{Source}

National Cancer Institute. ACER2 Gene. NCI Thesaurus. Code C103893.

This gene plays a role in sphingosine biosynthesis. 